\title{
INNOVATION IN THE AIR CARGO SECTOR: CASE STUDIES OF ESTONIA AND POLAND
}

\author{
Tarvo Niine ${ }^{1}$, Ene Kolbre ${ }^{2}$, Aleksandr Miina ${ }^{3}$, Malwina Dziugiel ${ }^{4}$ \\ ${ }^{1,2,3}$ School of Economics and Business Administration, Tallinn University of Technology, Estonia \\ ${ }^{4}$ Institute of Aviation, Warsaw, Poland
}

Submitted 13 October 2013; resubmitted 16 February 2014; accepted 5 January 2015

\begin{abstract}
Air cargo sector is a developing and dynamic field, where innovation can take place in a number of forms in the sense of technology as well as processes and business model alterations. The forefront of innovation in the sector lies 'at the top', i.e. around international airfreight hubs. In contrast, this study is aimed at mapping out the situation on the example of two regional airport hinterlands in Eastern Europe: Tallinn (Estonia) and Katowice (Poland), to identify the level and types of innovation present in air cargo service providing companies in these regions. The hypothesis of this study is that the level of innovation in the air cargo sector in the regions in question is both benefiting the existing cargo customers and sufficiently supporting the entrepreneurship development by attracting new customers to locate in the area and utilise air transport for their export despite the regions not being airfreight hubs in international sense. A survey was designed and conducted involving altogether 32 companies in the air cargo sector in Estonia and Poland and was carried out in the beginning of 2013. Additional information was obtained by expert interviews with selected participants in the framework of Baltic Air Cargo Network (BACN). The perceived level of innovation in both regions is relatively high in most types of innovation. Various improvements are mostly resulting in increased service quality and differentiation by quality rather than service price. Selected statistically, significant differences in data of two countries allow to understand two similar environments better. The outlooks of the sector in the regions are cautiously optimistic and the developments affect the existing exporters as well as create a suitable environment to attract new exporters and enable entrepreneurship growth in the future. It is interesting and valuable to air cargo stakeholders and authorities that air cargo service industry can be innovative and has growth potential even in regions with the modest number of direct flight destinations. Innovation comes to life via flexibility in transport services, such as the growth and systematic development of Road-Feeder Services (RFS), which allows remote regions to be better connected in the international networks.
\end{abstract}

Keywords: air cargo; innovation types; entrepreneurship development; Baltic Sea Region; Tallinn Airport; Katowice Airport.

\section{Introduction}

Innovation is increasingly recognised as having an important contribution to make to organisational success, performance and survival (Baregheh et al. 2012). It is now widely appreciated that in turbulent market economies, innovation is the elixir of life for firms, regardless of their size or other attributes. Growth, success and survival - all depends on the firms' ability to innovate on a continual basis (Varis, Littunen 2010).

Relations between innovation development and enterprise size have long been debated. Smaller firms are widely regarded as promoters of economic growth (Westhead, Storey 1994) and as entities being the most successful in creating, transferring and exploiting in- novations (Autio 1998; Fontes 1997; Kuratko, Hodgetts 2001). It has been suggested that large firms may smother creativity and may be sluggish in responding to new opportunities and customer needs. However, they have the capabilities to invest more in process innovations, while smaller enterprises put more effort into product innovations and are considered to be more innovative due to their flexibility (Cohen, Klepper 1996).

As is often pointed out, small firms have limited capabilities to screen market and technology trends, might have reactive attitudes towards innovation, difficulties in networking and the innovation development is based mostly on the experience and needs external support (Cohen, Klepper 1996; Forsman 2008; Hannula,

Corresponding author: Tarvo Niine

E-mail: tarvo.niine@ttu.ee 
Rantanen 2000; Scozzi et al. 2005; Forsman, Rantanen 2011). Other authors, e.g. Bertschek and Entorf (1996) have stated that there is no definite relationship between innovation and enterprise size.

Based on company life-cycle theories, one field of study has been the relation between the age of firm and its innovation activity and growth characteristics. Numerous studies have shown that the development of new and young firms is based on innovation (Churchill 1997; Scott, Bruce 1987; Wright et al. 2007).

Innovation development has been studied in various industrial settings and also in service sectors. Within manufacturing enterprises, innovation development has been studied with emphasis on the technology intensity of sector (Heidenreich 2009; Kirner et al. 2009; Pavitt 1984) while within service enterprises the emphasis has been on the knowledge intensity of sector (Amara et al. 2009; Miles 2000; Leiponen 2005). However, according to authors' knowledge, no studies have so far directly examined innovation development issues in the air cargo sector. Similarly, the state of the sector in the Baltic Sea Region has not been thoroughly and comparatively studied.

Air cargo has always been a special business - offering the fastest delivery times over medium and long distances, but especially across continents. To utilize the speed factor to maximum extent, airline networks are continuously expanding, making air industry more flexible compared to maritime transport, although not nearly as agile as road transport on reacting to demand changes. Alongside economic growth, the main demand drivers in the world are globalization, liberalization and lean inventory strategies. Furthermore, air cargo market is mostly driven by expansion of outsourcing and offshoring (Senguttuvan 2006). Rapid integration of world markets and demand for customized products has pushed air cargo to dominance in the 21st century market place (Kleindorfer, Visvikis 2007).

Air cargo sector, in practice, is developing the quickest 'at the top', i.e. around international airfreight hubs. In contrast, this study is aimed at mapping out the situation on the example of two regional airport hinterlands in Eastern Europe: Tallinn (Estonia) and Katowice (Poland). Firstly, the study needs to identify how the air cargo service providers in Tallinn and Katowice evaluate the current situation and developments in the industry and what is their view of developments in the local entrepreneurship, which forms their customer base in export. Secondly, it is important to understand the viewpoint of forwarders, who can be expected to have a wider look on the air cargo industry than the actual service providers (airlines, sales agents, terminals etc.) and also understand much better the local air cargo exporters, the local entrepreneurship potential regarding air cargo and their motivation to expand.

This paper is structured as follows: the literature review on the innovation development, the methodology providing details of data collection, the results are discussed with the aim of answering proposed purpose and hypothesis; the conclusions of the study providing the implications for future research are formulated in the last section.

\section{Theoretical Background and Research Hypotheses}

The innovation is widely and deeply studied, but also highly debated discipline. Quite often innovation is equalled with the development of new products and services. In fact, Schumpeter (1934) was one of the first researchers who emphasised the importance of new products for economic growth. On the other hand, innovation as such is not only product or service development. Innovation could be defined as management of all activities, which are connected with development of new product/service ideas, technology, manufacturing and marketing processes (Myers, Marquis 1969). Thus, innovation is the management process with products or services being the outputs of that process.

Innovation is different from 'invention' in that the latter is concerned with new ideas and developments of a mechanical or a technical nature, whereas the emphasis on the commercial application of a new idea is what distinguishes 'innovation' (Mitra 2012). The simple formula clarifies this statement (Trott 2011):

\section{Innovation $=$ theoretical concept + \\ technical solution + business usage.}

In this equation, theoretical concept equals with invention, which in turn has to be technically advanced into a feasibly produced and marketable product and then successfully implemented in business with a goal of bringing direct benefit to the organisation. Thus, the innovation is complex management of all those activities together.

In the past, different researches have indicated the polar views of sources of innovation. In general, they could be divided in three main schools of thought:

1. Market-based view of innovation. Market conditions provide the context, which facilitate or constrain the extent of firm innovation activity (Slater, Narver 1994; Porter 1980, 1985). The key issues here could be identified as ability of the firms to recognise opportunities in the market place and that firm should have this ability to scan the environment effectively (Cohen, Levinthal 1990; Trott 1998).

2. Resource-based view of the firm. A firm's own resources provide a much more stable context in which to develop its innovation activity, and to shape its markets in accordance to its own view (Tidd 2000; Shavinina 2003; Patel, Pavitt 2001). The resource-based view focuses of the firm's own resources and capabilities, skills and knowledge.

3. Serendipity. Innovation is all due to luck and good fortune (Trott 2011). Many cases in history show that new successful ideas are created due to unexpected discovery.

Recent studies have more and more focused on interactions of all three mentioned models above and have created an interactive model, where market-based, technology-based and serendipity models are linked together (Fig. 1). 


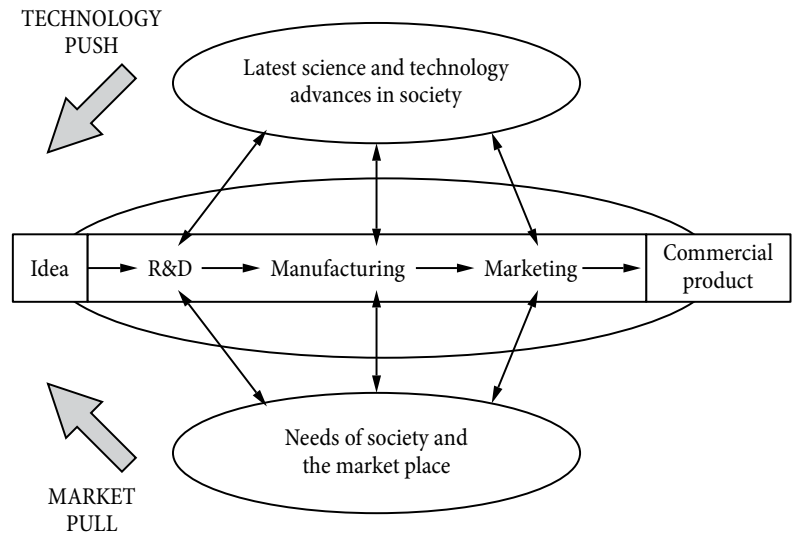

Fig. 1. Interactive model of innovation (Rothwell, Zegweld 1985)

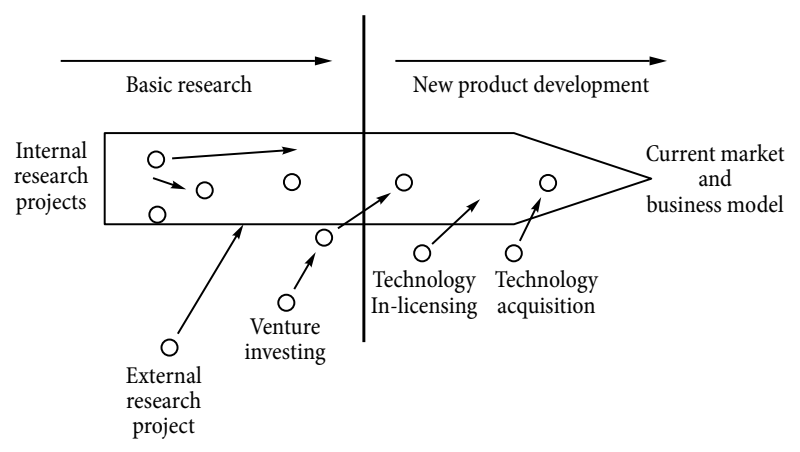

Fig. 2. Open innovation (Chesbrough 2005)

Nowadays, the term open innovation (Fig. 2) is often used to describe how companies should act in order to be able to be successful in innovation field.

To conclude, there is no agreement of which model is more valid for the answer of the question of innovation source and therefore each company (or business segment) should be viewed and studied on its own. Organisations are often unable to explain what they do; they could be competent without being able to create a theoretical framework of their actions (Polanyi 1966).

An organisation could face different types of innovations: product or service innovation; process innovation (new technological process); organisational innovation (new company structure); management innovation (new way of process management within the company); and marketing innovation (new sales or marketing approach) (Trott 2011). The first one is mostly focused on external customers, though others might be applied for the internal customers (for the organisation itself) as well.

The first goal of our research is to study the level and types of innovation in the sector in question. Furthermore, the hypothesis of this study is that the level of innovation in the air cargo sector in the selected regions is both benefiting the existing cargo customers as well as sufficiently supporting the entrepreneurship development by attracting new customers to locate in the area and utilise air transport for their export despite the regions not being airfreight hubs in international sense.
The study is based on expert interviews with various sector representatives in both mentioned regions as well as a survey aimed at wider array of sector participants.

\section{Research Methodology and Data}

The study started in the framework of a project Baltic Air Cargo Network (BACN), which was aimed at mapping the status and outlooks of the air cargo sector in the Baltic Sea Region. The project was funded by the Baltic Sea Region Programme 2007-2013 relating to improving internal accessibility and harmonised development of the air cargo in the region. The keywords researched in the project scope were structural challenges, ICT challenges and optimal development scenarios ways to ensure the potential of local airports is acknowledged and developed accordingly and to support the availability of various air cargo solutions to all potential customers.

On one hand, some airports in the project were concerned about potentially having invested too much into 'concrete' and increasing capacity, with relatively less focus on finding ways how to differentiate and market air cargo services to specific target groups. On the other hand, other countries with lower GPD mainly asked the question which investments should be done in the future.

The first expert interviews with the regional stakeholders were carried out with the general intent of understanding the business situation. The qualitative approach leads to understanding that the sector is mostly optimistic about the future outlooks and points out numerous developments in the recent history - both in own organisation as well as in the sector in general.

While the project covered all major airports in the Baltic Sea Region, the specific study on innovation was carried out in two selected airports, Tallinn and Katowice, which had specific interests on the topic locally and two of them were from different economic backgrounds, shared in closer view many similar characteristics: importance for local exporters, proximity to larger air hubs, considerably volatile cargo volumes and relative difficulty to attract new airlines to name a few.

In 2012, Tallinn Airport handled 23900 tonnes of freight and mail, which is $30 \%$ increase over 2011 volume. The growth between 2010 and 2011 was even higher $-53 \%$. This is still in contrast to the peak from 2008, which saw the record volume, over 40000 tonnes. However, most of it is transit cargo. Export, as one of the purposes of this study, matters the most. In Tallinn Airport, export volume was 2500 tonnes in 2012. However, this does not account for Road-Feeder Services (RFS) volumes, which, although handled by providers located at Tallinn Airport are leaving the country on a truck. It is estimated that at least $2 / 3$ of total local air cargo exports utilise RFS. The future export volumes at Tallinn Airport are forecasted to grow with moderate pace probably not exceeding $10 \%$ per year in a long run.

Over the course of recent years, the annual cargo volume through Katowice Airport has remained around 
10000 tonnes, facing similar issues of partially lacking statistics. It is considered as one of the most perspective airports in Poland with no constrains concerning operational terms, future expansion or environmental issues. Due to a long distance from the city, the focus is mainly on charters and cargo transport. The growth of Katowice Airport volumes is forecasted to be slightly higher compared to Tallinn Airport, mostly due to stronger economic development in the hinterland.

To understand innovation specifically in that context and its potential contribution to entrepreneurship development, a survey was designed and conducted. Such a quantitative research method is suitable for measuring phenomena (Hair et al. 2003) and enables this study to generalise in identifying innovation patterns. Questionnaires are also the main method of data collection in many previous innovation studies (Damanpour, Gopalakrishnan 2001; Dibrell et al. 2008; Hult et al. 2004; Forsman 2008; Laforet, Tann 2006; Subramanian, Nilakanta 1996).

Questionnaire included sections of the regional air cargo outlooks and development issues, innovation level and its resulting effects in companies and the actions undertaken to reach innovation. The questionnaire was built on the five types of innovation identified by Trott (2011) and surveyed the resulting effects of innovation in four categories: price, service quality, service volume and differentiation. Most questions used Likert-style rating scale to elicit respondents' view of the level of engagement of their organisation with the activities embedded in the statements. The survey was initially piloted with two forwarders that suggested slight alterations of wordings for better clarity over the intent of the questions. The average time to answer was around 20 minutes.

Our web-platform based questionnaire was sent to companies' mid- or top-level managers directly or alternatively used as a tool in an interview setting to obtain additional comments and viewpoints. This allowed us to get a decent amount of responses. In the case of Estonian air cargo service providers, we estimate the total number of relevant companies to be around 50 (the line is not clear, for example, many forwarders deal with air cargo only with marginal volumes and are by no means identifying themselves as important participants in the air cargo sector). Of that 50, the responses of 21 Estonian companies (including local offices of international companies) were gathered.

Around the Katowice area, the number of companies in the sector is by large of similar magnitude and of these, 11 responses were obtained. Collected data was first entered and coded in Microsoft Excel, and then imported into SPSS Statistics for descriptive analysis.

The utilised statistical approach was mostly the standard traditional Student's $t$-test, which in our case relates to comparing two data sets to identify significant differences between Tallinn and Katowice the air cargo sector innovation level and other related characteristics. On the first hand, it was the aim of the research to be specific enough to reach the level of differences in perceived innovation environment between the two exam- ples, but on the other hand, to be general enough not to require too much time and effort from the respondents, who, after all, might not be too familiar with what constitutes innovation in our theoretical perspective.

\section{Findings}

A survey gathered altogether 32 responses: 21 from providers of air cargo services in Estonia and 11 from Poland. As for company type, there were 5 airlines and airline sales agents, 6 cargo terminal operators and providers of ground services and 21 forwarding companies (from micro companies to international service integrators). The variety of company sizes was substantial ranging from micro companies (such as dedicated air cargo forwarders or smaller cargo terminals) to large multinational companies. The exact classification is difficult due to many respondents being large in numbers and in turnover but with possibly only a few people focusing on air transport operations (as is typical with many forwarding companies).

\subsection{General Trends on the Local Air Cargo Market}

To reach better understanding about the development perspectives of the air cargo sector in the region in general, the survey asked respondents to evaluate the developments on the local market in 13 categories listed in Table 1. The question utilised a five-point scale ranging from 'significant fall-back' to 'significant development'. The answers presented here are supported by similar findings from the expert interviews carried out earlier.

For Tallinn, the respondents see the modest development in sector capacities and some potential increase in flight frequencies of passenger airlines and RFS, in contrast to chartered or dedicated cargo airline perspectives, which are seen as improbable. In addition to service capacities, the service quality (handling quality, customs clearance quality) is also expected to increase. The effect on total attractiveness of the airport to cargo customers is seen as slightly developing - the customer base will grow but it will only influence entrepreneurship activity in the region to an extent. This can be interpreted as the air cargo clients' niche is increasing, but not considerably to have large economic impact. The survey asked the developments in two timeframes: over a 2-year and 5-year horizon. The 5-year perspective, according to Estonian respondents, is largely similar, if ever so slightly more optimistic - the situation could be labelled 'slow growth'.

The development outlooks of Katowice Airport appear to be slightly more optimistic, with respondents also eyeing more frequent charter cargo flights and expecting RFS to grow faster compared to Tallinn. Similarly, to Tallinn, further growth is expected over 5-year horizon, when the economic environment is expected to be more stable compared to current uncertainties. The effect on airport attractiveness and entrepreneurship activity in Katowice is seen substantially higher compared to Tallinn and to cater for the increase in cargo volumes, the need for more terminals at the airport is perceived. This 
Table 1. Dominant viewpoint of local air cargo sector participants on general air cargo market developments (in timeframe of 2 years) in Tallinn and Katowice

\begin{tabular}{l|l|l}
\hline \multicolumn{1}{c|}{ Sector development category } & \multicolumn{1}{c}{ Tallinn } & \multicolumn{1}{c}{ Katowice } \\
\hline $\begin{array}{l}\text { Passenger airline frequency and the number of destinations } \\
\text { from the airport }\end{array}$ & Slight development (62\%) & Slight development (64\%) \\
\hline Charter cargo flight frequency & $\begin{array}{l}\text { No changes expected } 47 \% / \\
\text { slight development } 47 \%\end{array}$ & Slight development (64\%) \\
\hline Regular cargo airline situation & No changes expected 67\% & $\begin{array}{l}\text { No changes expected (45\%) / } \\
\text { slight development (45\%) }\end{array}$ \\
\hline RFS truck frequency & Slight development (57\%) & Slight development (54\%) \\
\hline RFS coverage & No changes expected (57\%) & Slight development (64\%) \\
\hline Competition density in air cargo forwarding & $\begin{array}{l}\text { No changes expected (47\%) / } \\
\text { slight development (47\%) }\end{array}$ & Slight development (45\%) \\
\hline The number of cargo terminals at airport & No changes expected (91\%) & Slight development (54\%) \\
\hline The price of air cargo from the end customer point of view & Slight development (81\%) & No changes expected (64\%) \\
\hline Cargo handling quality at airport & Slight development (81\%) & No changes expected (54\%) \\
\hline Customs speed and quality at airport & Slight development (76\%) & No changes expected (54\%) \\
\hline $\begin{array}{l}\text { The number of exporters using air cargo in the region } \\
\text { and volumes }\end{array}$ & Slight development (67\%) & Slight development (64\%) \\
\hline Total attractiveness of airport to customers & Slight development (53\%) & Slight development (81\%) \\
\hline The effect of air cargo service to entrepreneurship activity in region & Slight development (53\%) & Slight development (91\%) \\
\hline
\end{tabular}

is also taken into account in Katowice Airport expansion plans as adequate investments are made to increase capacities and increase service quality for both passenger as well as cargo customers. Over 5-year perspective, the respondents of Katowice are pointing out even 'substantial developments' in last two categories. The outlook of Katowice Airport could therefore be labelled as 'optimistic growth'. Such result is similar to findings from the studies with much more general research intent from the BACN project.

\subsection{Innovation in Air Cargo Service Companies}

When queried about the general level of innovation in the local air cargo sector on a 5-point scale, the most common answer in both regions was 3 with Katowice service providers seen slightly more innovative (average 3.1) than their Estonian counterparts (average 2.8). However, the data indicates that there is no statistically significant difference between the levels of innovation in our two regions (Student's $t$-test $p=0.24$ ). The answers did not show high variance, so the interpretation is that the general innovation level in the air cargo at the moment in both regions is moderate and similar. This, should not however be interpreted as there would be no differences to some aspects of innovation in detail, which are commented upon below.

One question of the survey was specifically aimed to determine if the changes in the company were more initiated by the perceived needs of the company or the market pressure. The answers for both regions confirm that the market influence is notable and in many cases the driving force of innovation. In Katowice region, 9 out of 11 respondents evaluate the market pressure to innovate as ' 3 ' on a 3 -point scale. In Tallinn region, the same answers divided 10 ' 2 ' and 8 ' 3 ' to market pressures. This does not mean that all innovation is purely driven by market forces, but a large proportion of it appears to be. Furthermore, although Estonian and Polish companies had similar level of inner motivation to innovate, but there appeared a statistically significant difference between the levels of perceived competitive pressure to innovate (Student's $t$-test $p=0.01$ ). This competitive pressure in Katowice area can result in higher level of innovation over time, compared to more stable and conservative case in Tallinn area. This could be seen as the result of not only growth in the air cargo utilising industry in the region but also reflects a higher level of competition for cargo between adjacent airports and between air and road transport. From an alternative angle, it could be treated as the market pressure in Tallinn air cargo area is the same from existing customers and competing solutions, but lack the extra scope of higher customer base growth expectation.

Next, the respondents were asked to evaluate the level of different types of innovation in their own company on a $0-3$ point scale, where:

- 0 - 'no occurrence identified';

- 1 - 'changes of lesser importance';

- 2 - 'changes of average importance';

- 3 - 'changes of significant importance'.

The responses are summarised in Table 2. The numbers point out that mostly the companies perceive service and process innovation and are mostly moderately active in the developments. Organisational and management innovation is not seen as a first priority, but even in these aspects, many companies are moving forward. Finally, perhaps surprisingly, marketing innovation came out in many companies to be close to equal 
to service and process innovation, at least by perceived level of importance. This suggests that companies are indeed in tight competition and are focusing their efforts not only on the services but also on the ways to reach new customers.

It was interesting to see that even though the market pressure to innovation is much higher for the companies in Katowice area, where only type of innovation that is showing significant differences between the two countries is management innovation (Student's $t$-test $p=0.03$ ). This might suggest that innovation is more embedded to the typical company culture in Katowice region. It was also pointed out in a few interviews that both process as well as management changes are perceived as part of everyday business. Alternatively, this could just reflect the differences of typical sector organisations. As the sector in Estonia is mostly smaller, so are many companies and in such environment changes in management would not be that clearly perceived.

Taking a closer look to the results of five innovation types mentioned in every company, each aspect of innovation was viewed in four categories: the effect on service price, the effect on service quality, the effect on service volume and the effect on being able to differentiate on the market. The same 3-point scale was used as in the previous question with no / lesser / average / significant influence. The following Tables 3-7 present the results.

Subtle differences can be spotted in answers from the two regions, though the only statistically significant difference is in influence on service quality, favouring Polish companies. It appears that in some cases, service innovation can have notable impact on the service price, but it also depends if the company has the power and wants to use this new service to leverage the impact. It is logical that the biggest impact of service innovation is to increase the quality, that is expected by the customers and in turn, it can also attract new customers. In some cases, creating new services also allows companies to clearly differentiate themselves, whereas in other cases, it could be suggested, is more about serving the existing customers better rather than attracting a notable amount of new customers. Specific examples of improving service quality, as it appeared from the interviews, are foremost the efforts to advance the ability to offer wider pool of transit routes to customers. This is achieved by cooperation networks and better databases, which also shorten quotation cycles and make negotiations easier.

Table 2. Air cargo service providers distribution by perceived innovation levels in own company (in last two years)

\begin{tabular}{lcccc|cccc}
\hline \multirow{2}{*}{ Types of innovation } & \multicolumn{4}{c|}{ Tallinn } & \multicolumn{5}{c}{ Katowice } \\
\cline { 2 - 10 } & 0 & 1 & 2 & 3 & 0 & 1 & 2 & 3 \\
\hline Service innovation & 1 & 6 & $\mathbf{1 0}$ & 4 & 0 & 3 & $\mathbf{6}$ & 2 \\
\hline Process innovation & 2 & 2 & $\mathbf{9}$ & 8 & 0 & 2 & $\mathbf{5}$ & 4 \\
\hline $\begin{array}{l}\text { Organisational } \\
\text { innovation }\end{array}$ & $\mathbf{1 1}$ & 6 & 4 & 0 & 3 & $\mathbf{4}$ & 3 & 1 \\
\hline $\begin{array}{l}\text { Management } \\
\text { innovation }\end{array}$ & $\mathbf{1 5}$ & 4 & 1 & 1 & 2 & $\mathbf{6}$ & 3 & 0 \\
\hline Marketing innovation & 4 & 6 & 7 & 4 & 0 & $\mathbf{5}$ & 5 & 1 \\
\hline
\end{tabular}

Table 3. Service innovation influences in the air cargo of Tallinn and Katowice regions

\begin{tabular}{lcccc|cccc}
\hline \multirow{2}{*}{ Service innovation } & \multicolumn{4}{c|}{ Tallinn } & \multicolumn{5}{c}{ Katowice } \\
\cline { 2 - 9 } & 0 & 1 & 2 & 3 & 0 & 1 & 2 & 3 \\
\hline Influence on price & $\mathbf{9}$ & 6 & 5 & 1 & 3 & 2 & $\mathbf{6}$ & 0 \\
\hline $\begin{array}{l}\text { Influence on service } \\
\text { quality }\end{array}$ & 1 & 1 & $\mathbf{1 1}$ & 8 & 0 & 0 & 3 & $\mathbf{8}$ \\
\hline $\begin{array}{l}\text { Influence on sales } \\
\text { volume }\end{array}$ & 2 & $\mathbf{8}$ & 7 & 4 & 0 & 3 & $\mathbf{5}$ & 3 \\
\hline $\begin{array}{l}\text { Influence on } \\
\text { differentiation }\end{array}$ & 4 & 3 & 5 & $\mathbf{9}$ & 1 & $\mathbf{7}$ & 3 & 0 \\
\hline
\end{tabular}

Table 4. Process innovation influences in the air cargo of Tallinn and Katowice regions

\begin{tabular}{lcccc|cccc}
\hline \multirow{2}{*}{ Process innovation } & \multicolumn{4}{c|}{ Tallinn } & \multicolumn{5}{c}{ Katowice } \\
\cline { 2 - 10 } & 0 & 1 & 2 & 3 & 0 & 1 & 2 & 3 \\
\hline Influence on price & $\mathbf{1 2}$ & 5 & 3 & 1 & 3 & 3 & 2 & 3 \\
\hline $\begin{array}{l}\text { Influence on service } \\
\text { quality }\end{array}$ & 4 & 1 & $\mathbf{8}$ & $\mathbf{8}$ & 0 & 1 & $\mathbf{6}$ & 4 \\
\hline $\begin{array}{l}\text { Influence on sales } \\
\text { volume }\end{array}$ & 6 & $\mathbf{9}$ & 5 & 1 & 1 & 3 & $\mathbf{5}$ & 2 \\
\hline $\begin{array}{l}\text { Influence on } \\
\text { differentiation }\end{array}$ & 4 & 6 & $\mathbf{7}$ & 4 & 2 & $\mathbf{5}$ & 4 & 0 \\
\hline
\end{tabular}

Table 5. Organisation innovation influences the in air cargo of Tallinn and Katowice regions

\begin{tabular}{lcccc|cccc}
\hline \multicolumn{1}{c}{$\begin{array}{l}\text { Organisation } \\
\text { innovation }\end{array}$} & \multicolumn{4}{c|}{ Tallinn } & \multicolumn{5}{c}{ Katowice } \\
\cline { 2 - 9 } & 0 & 1 & 2 & 3 & 0 & 1 & 2 & 3 \\
\hline Influence on price & $\mathbf{1 8}$ & 2 & 1 & 0 & $\mathbf{5}$ & 4 & 1 & 1 \\
\hline $\begin{array}{l}\text { Influence on service } \\
\text { quality }\end{array}$ & $\mathbf{1 1}$ & 2 & 4 & 4 & 2 & $\mathbf{4}$ & 3 & 2 \\
\hline $\begin{array}{l}\text { Influence on sales } \\
\text { volume }\end{array}$ & $\mathbf{1 1}$ & 5 & 3 & 2 & 3 & $\mathbf{4}$ & 3 & 1 \\
\hline $\begin{array}{l}\text { Influence on } \\
\text { differentiation }\end{array}$ & $\mathbf{1 1}$ & 7 & 1 & 2 & $\mathbf{5}$ & 3 & 3 & 0 \\
\hline
\end{tabular}

Table 6. Management innovation influences in the air cargo of Tallinn and Katowice regions

\begin{tabular}{lcccc|cccc}
\hline \multicolumn{1}{c}{$\begin{array}{c}\text { Management } \\
\text { innovation }\end{array}$} & \multicolumn{4}{c|}{ Tallinn } & \multicolumn{5}{c}{ Katowice } \\
\cline { 2 - 10 } & 0 & 1 & 2 & 3 & 0 & 1 & 2 & 3 \\
\hline Influence on price & $\mathbf{2 0}$ & 0 & 1 & 0 & $\mathbf{5}$ & 2 & 4 & 0 \\
\hline $\begin{array}{l}\text { Influence on service } \\
\text { quality }\end{array}$ & $\mathbf{1 5}$ & 2 & 3 & 1 & 3 & 2 & $\mathbf{5}$ & 1 \\
\hline $\begin{array}{l}\text { Influence on sales } \\
\text { volume }\end{array}$ & $\mathbf{1 6}$ & 2 & 3 & 0 & $\mathbf{4}$ & 3 & 2 & 2 \\
\hline $\begin{array}{l}\text { Influence on } \\
\text { differentiation }\end{array}$ & $\mathbf{1 6}$ & 3 & 1 & 1 & $\mathbf{6}$ & 2 & 3 & 0 \\
\hline
\end{tabular}

Table 7. Marketing innovation influences in the air cargo of Tallinn and Katowice regions

\begin{tabular}{lcccc|cccc}
\hline \multirow{1}{*}{$\begin{array}{l}\text { Marketing } \\
\text { innovation }\end{array}$} & 0 & 1 & 2 & 3 & 0 & 1 & 2 & 3 \\
\cline { 2 - 10 } & $\mathbf{1 5}$ & 3 & 3 & 0 & 4 & 1 & $\mathbf{5}$ & 1 \\
\hline Influence on price & $\mathbf{1 1}$ & 2 & 5 & 3 & 1 & 2 & $\mathbf{7}$ & 1 \\
\hline $\begin{array}{l}\text { Influence on service } \\
\text { quality }\end{array}$ & 5 & 5 & $\mathbf{7}$ & 4 & 1 & 1 & $\mathbf{8}$ & 1 \\
\hline $\begin{array}{l}\text { Influence on sales } \\
\text { volume }\end{array}$ & $\mathbf{6}$ & $\mathbf{6}$ & 4 & 5 & 2 & 4 & $\mathbf{5}$ & 0 \\
\hline $\begin{array}{l}\text { Influence on } \\
\text { differentiation }\end{array}$ & & & & & & & &
\end{tabular}


Another important example of an element of innovation benefiting the air cargo in peripheral regions such as Tallinn, is the development of RFS that assure road transport links to adjacent air hubs. We observed in many cases that efforts are made to achieve better market overview and constantly keep the existing network optimal, which is still challenging, considering the lack of generalised cargo statistics in terms of RFS cargo types and destinations. Flexibility offered by such services allows remote regions to be better connected in the international networks and give in many cases a good trade-off in losing in total delivery time (compared to integrated courier-networks) but gaining a much more affordable transit price. The RFS services also ensure good connection even in the decline of passenger airlines destinations, which is at the moment a serious issue for Tallinn Airport due to the cuts in the local Estonian Air.

The effects of process innovation can be even wider, but again the focus is on increasing the quality of the processes. Most respondents pointed out IT-system advancement as a main means of process innovation, which can logically have at least some effect on the cost levels as well. In some cases, it can attract new customers, whereas in others it is aimed at higher satisfaction of existing customers. It appears from the data that process innovation only seldom influences the service price for the end customer, even though the costs might be influenced more often. For Polish companies, influence on price is felt more, which matches their higher competitive pressure finding. ICT solutions to improve speed and precision of communication are on the forefront of process innovation. Similarly, replacing paper documents with digital communication is still an ongoing effort in the sector (relating to initiatives such as IATA e-freight).

It is perhaps logical to assume that organisation innovation should have more 'inside-focused' than customer-perceived benefits. However, parts of our data suggest that in (somewhat rare) cases of organisation innovation (mostly structural changes), there is more effect felt on the service quality than on the service price. Due to low numbers of companies experiencing organisation innovation, the findings are not statistically valid though.

Management innovation, similarly to organisation innovation, appears to show more differences between the regions than the other types. The data encourages pointing out that there are existing success stories on the air cargo market about all types of innovation and it can affect both quality and service volumes.

It could be said that for some companies there can be some missed opportunities, although, of course, the situation heavily depends on a given context - the fact that some companies can reap the benefits of organisational / management changes does not automatically mean that it is readily available for everyone.

As it appears, social networking is a keyword also in the air cargo business and it is perceived to have the potential to increase the customer base. Additionally, finding new ways to approach customers also can have an effect on price and on total perception of service quality.

Finally, the influences of all five-innovation types to all four aspects were summarised, keeping in mind that the average general sector innovation level as well as personal evaluation averages turned out much similar in both studied regions (excluding management innovation). This resulted in four scales of the overall effect of innovation in a company to a given outcome between $0-15$, as shown in Table 8.

The data firstly suggested that the biggest impact of innovation in the air cargo business, according to the studied regions, lies in improving service quality, which ranks more important than generating new sales volume. The typical innovation in the air cargo business leads to improved quality rather than lower price. In addition, it appears that in some cases improving service quality is not enough to clearly differentiate on the market - hence the lower effect on generating additional customers.

Secondly, even though the level of innovation appears similar comparing Estonian companies to Polish ones, the latter are showing significantly higher outcomes of innovation in price and service quality. This might be the result of both environmental factors as well as own actions. Whereas the environmental factors fall outside the scope of this research, the final section of the survey focused on a few selected actions to facilitate innovation. The survey asked, how much had the companies been involved in actions listed in Table 9, utilising the same 3-point scale, where in this case: 0 - 'haven't done anything', 3 - 'we have done much and thoroughly'.

Table 8. Summarised influence of innovation in a company in Tallinn and Katowice regions

\begin{tabular}{lccc}
\hline \multicolumn{1}{c}{ Influence } & $\begin{array}{c}\text { Average } \\
\text { EST }\end{array}$ & $\begin{array}{c}\text { Average } \\
\text { POL }\end{array}$ & $\begin{array}{c}\text { Student's } \\
\text {-test }\end{array}$ \\
\hline Influence on price & 2.28 & 5.72 & 0.033 \\
\hline $\begin{array}{l}\text { Influence on service } \\
\text { quality }\end{array}$ & 6.76 & 9.54 & 0.014 \\
\hline $\begin{array}{l}\text { Influence on sales } \\
\text { volume }\end{array}$ & 5.33 & 7.91 & 0.066 \\
\hline $\begin{array}{l}\text { Influence on } \\
\text { differentiation }\end{array}$ & 5.90 & 5.12 & 0.57 \\
\hline
\end{tabular}

Table 9. Activities to facilitate innovation in the air cargo of Tallinn and Katowice regions

\begin{tabular}{lllll|llll}
\hline \multirow{1}{*}{$\begin{array}{c}\text { Activities to facilitate } \\
\text { innovation }\end{array}$} & \multicolumn{4}{c|}{ Tallinn } & \multicolumn{5}{c}{ Katowice } \\
\cline { 2 - 10 } & 0 & 1 & 2 & 3 & 0 & 1 & 2 & 3 \\
\hline Improving processes & 0 & 3 & $\mathbf{1 2}$ & 6 & 0 & 1 & $\mathbf{5}$ & $\mathbf{5}$ \\
\hline $\begin{array}{l}\text { studying customer } \\
\text { satisfaction }\end{array}$ & 5 & 3 & $\mathbf{8}$ & 5 & 1 & 2 & $\mathbf{5}$ & 3 \\
\hline $\begin{array}{l}\text { Investing into employees' } \\
\text { competences }\end{array}$ & 1 & 2 & $\mathbf{1 1}$ & 7 & 0 & 3 & $\mathbf{4}$ & 4 \\
\hline $\begin{array}{l}\text { Studying industry best } \\
\text { practices }\end{array}$ & 2 & 6 & $\mathbf{1 1}$ & 2 & 0 & 1 & $\mathbf{8}$ & 2 \\
\hline $\begin{array}{l}\text { Cooperating with academic } \\
\text { and research institutions }\end{array}$ & $\mathbf{1 3}$ & 5 & 2 & 1 & 5 & 3 & 1 & 2 \\
\hline
\end{tabular}


The case appears to be that most companies have made an effort in most mentioned areas. There is a statistically significant difference in only one factor surveyed, which is knowledge about the best practices of the international industry (Student's $t$-test $p=0.05$ ). It appears that Polish companies are more knowledgeable about the industry leaders than their Estonian counterparts. Probably this is the result of the higher market pressure and also one contributing factor to reaping more benefits from innovation.

\section{Conclusions}

By Baregheh et al. (2012), innovation is increasingly recognised as having an important contribution to make to organisational success, performance and survival. Our data on the air cargo sector participants confirms it. The survey showed that innovation is taking place in various forms in the studied regions, benefiting both existing customers and attracting new customers. The advancements in a developing sector are expected to have a long-term effect on customer-markets, which does not only end with faster and better quality service. Although traditionally in cargo aviation, the first priority is and remains speed, it is also necessary to have enough wellfunctioning competition so that air cargo clients would be served with a multitude of options on different balancing points between speed, service quality and cost. In addition to greater value creation through lower cost, shorter time, customised services and service quality, innovation in air cargo sector can also support regional entrepreneurship by increasing the number of exporters and their production output.

In conclusion, we have observed selected differences to show that differences exist and that these differences might not only be statistically significant but might also serve as a foundation for the greater air cargo sector development in the region. The market forces create the main pressure to innovate, but inner drivers towards innovation also contribute to it according to our data. In comparison between the two studied regions, Katowice area air cargo service providing companies are experiencing higher competitive pressure and this leads to higher-level benefits obtained through various forms of innovation. The case of Tallinn shows that even with lower growth outlooks of air cargo utilising industries in the region, the companies do not generally see the market as stagnating.

According to the expert interviews, we are agreeing with the position of Bertschek and Entorf (1996), who have stated that there is no definite relationship between innovation and enterprise size. Similarly, among the more innovative companies surveyed, there was a range of various company sizes in between 3 and 300 employees. Furthermore, we could observe no relation between company age and the level of innovation as in our case, both fresh start-ups and companies with 10-15 years of experience could offer a multitude of examples about recent innovations.

On the topic of sources of innovation, the interviewed companies mostly pointed out the importance of learning from industry best practices and focusing on employee training. On many cases of companies studied, we can suggest the innovation does not only come from the top-level management but also from employee involvement and competence development. The findings appear to suit the 'open innovation' approach. The present level of innovation in the regions studied also supports market dynamics and entrepreneurship inside the air cargo service sector. In some cases observed, companies had been founded recently mostly because of their idea to do something different from competition.

The economic reality of the regions is defining growth scenarios, which show modest growth. We can assert based on our data that should the positive demand scenarios come to life, the air cargo industry is ready to react to the changes both mentally and in actual service capacity. Therefore, we can conclude that the air cargo sector in the studied regions should not be treated as a bottleneck in entrepreneurship growth. If the right mix of entrepreneurship environment is present, the cargo volumes served can easily increase.

\section{References}

Amara, N.; Landry, R.; Doloreux, D. 2009. Patterns of innovation in knowledge-intensive business services, The Service Industries Journal 29(4): 407-430. http://dx.doi.org/10.1080/02642060802307847

Autio, E. 1998. Evaluation of RTD in regional systems of innovation, European Planning Studies 6(2): 131-140. http://dx.doi.org/10.1080/09654319808720451

Baregheh, A.; Rowley, J.; Sambrook, S.; Davies, D. 2012. Innovation in food sector SMEs, Journal of Small Business and Enterprise Development 19(2): 300-321. http://dx.doi.org/10.1108/14626001211223919

Bertschek, I.; Entorf, H. 1996. On nonparametric estimation of the Schumpeterian link between innovation and firm size: evidence from Belgium, France, and Germany, Empirical Economics 21(3): 401-426. http://dx.doi.org/10.1007/BF01179865

Chesbrough, H. W. 2005. Open Innovation: the New Imperative for Creating and Profiting from Technology. Harvard Business Review Press. 272 p.

Churchill, N. C. 1997. The six key phases of company growth, in S. Birley, D. F. Muzyka (Eds.). Mastering Enterprise: Your Single-Source Guide to Becoming an Entrepreneur, 213-219.

Cohen, W. M.; Klepper, S. 1996. Firm size and the nature of innovation within industries: the case of process and product R\&D, The Review of Economics and Statistics 78(2): 232243. http://dx.doi.org/10.2307/2109925

Cohen, W. M.; Levinthal, D. A. 1990. Absorptive capacity: a new perspective on learning and innovation, Administrative Science Quarterly 35(1): 128-152. http://dx.doi.org/10.2307/2393553

Damanpour, F.; Gopalakrishnan, S. 2001. The dynamics of the adoption of product and process innovations in organizations, Journal of Management Studies 38(1): 45-65. http://dx.doi.org/10.1111/1467-6486.00227

Dibrell, C.; Davis, P. S.; Craig, J. 2008. Fueling innovation through information technology in SMEs, Journal of Small Business Management 46(2): 203-218.

http://dx.doi.org/10.1111/j.1540-627X.2008.00240.x

Fontes, M. 1997. Creation and development of new technolo- 
gy-based firms in peripheral economies, in D. Jones-Evans, M. Klofsten (Eds.). Technology, Innovation and Enterprise: the European Experience, 107-147.

Forsman, H. 2008. Business development success in SMEs: a case study approach, Journal of Small Business and Enterprise Development 15(3): 606-622. http://dx.doi.org/10.1108/14626000810892382

Forsman, H.; Rantanen, H. 2011. Small manufacturing and service enterprises as innovators: a comparison by size, European Journal of Innovation Management 14(1): 27-50. http://dx.doi.org/10.1108/14601061111104689

Hair, J. F.; Babin, B.; Money, A. H.; Samouel, P. 2003. Essentials of Business Research Methods. Wiley. 464 p.

Hannula, M.; Rantanen, H. 2000. Obstacles restraining productivity improvement in the Finnish SME sector, International Journal of Business Performance Management (IJBPM) 2(1-3): 171-179.

http://dx.doi.org/10.1504/IJBPM.2000.000070

Heidenreich, M. 2009. Innovation patterns and location of European low- and medium-technology industries, Research Policy 38(3): 483-494. http://dx.doi.org/10.1016/j.respol.2008.10.005

Hult, G. T. M.; Hurley, R. F.; Knight, G. A. 2004. Innovativeness: its antecedents and impact on business performance, Industrial Marketing Management 33(5): 429-438. http://dx.doi.org/10.1016/j.indmarman.2003.08.015

Kirner, E.; Kinkel, S.; Jaeger, A. 2009. Innovation paths and the innovation performance of low-technology firms: an empirical analysis of German industry, Research Policy 38(3): 447-458. http://dx.doi.org/10.1016/j.respol.2008.10.011

Kleindorfer, P. R.; Visvikis, I. 2007. Integration of Financial and Physical Networks in Global Logistics. Working Paper \# 2007-11-06. University of Pennsylvania, US. 25 p.

Kuratko, D. F.; Hodgetts, R. M. 2001. Entrepreneurship: A Contemporary Approach. Harcourt College Publishers. 722 p.

Laforet, S.; Tann, J. 2006. Innovative characteristics of small manufacturing firms, Journal of Small Business and Enterprise Development 13(3): 363-380. http://dx.doi.org/10.1108/14626000610680253

Leiponen, A. 2005. Organization of knowledge and innovation: the case of Finnish business services, Industry and Innovation 12(2): 185-203. http://dx.doi.org/10.1080/13662710500087925

Miles, I. 2000. Services innovation: coming in the age of knowledge-based economy, International Journal of Innovation Management 4(4): 371-389. http://dx.doi.org/10.1142/S1363919600000202

Mitra, J. 2011. Entrepreneurship, Innovation and Regional Development. Routledge. 360 p.

Myers, S.; Marquis, D. G. 1969. Successful Industrial Innovations: a Study of Factors Underlying Innovation in Selected Firms. National Science Foundation. Washington, DC. 116 p.

Patel, P.; Pavitt, K. 2001. How technological competencies help define the core (not the boundaries) of the firm, in G. Dosi, R. R. Nelson, S. Winter (Eds.). The Nature and Dynamics of Organizational Capabilities, 313-333.

http://dx.doi.org/10.1093/0199248540.003.0012

Pavitt, K. 1984. Sectoral patterns of technical change: towards a taxonomy and a theory, Research Policy 13(6): 343-373. http://dx.doi.org/10.1016/0048-7333(84)90018-0

Polanyi, M. 1966. The Tacit Dimension. London: Routledge and Kegan Paul.

Porter, M. E. 1985. Competitive Strategy. Boston: Harvard University Press.

Porter, M. E. 1980. Competitive Strategy: Techniques for Analyz- ing Industries and Competitors. New York: The Free Press.

Rothwell, R.; Zegweld, W. 1985. Reindustrialisation and Technology. London: Longman.

Schumpeter, J. A. 1934. The Theory of Economic Development: an Inquiry into Profits, Capital, Credit, Interest, and the Business Cycle. Harvard University Press. 255 p.

Scott, M.; Bruce, R. 1987. Five stages of growth in small business, Long Range Planning 20(3): 45-52. http://dx.doi.org/10.1016/0024-6301(87)90071-9

Scozzi, B.; Garavelli, C.; Crowston, K. 2005. Methods for modelling and supporting innovation process in SMEs, European Journal of Innovation Management 8(1): 120-137. http://dx.doi.org/10.1108/14601060510578619

Senguttuvan, P. S. 2006. Air cargo: engine for economic growth and development - a case study of Asian Region, in $\mathrm{Na}$ tional Urban Freight Conference 2006 (METRANS 2006), 1-3 February 2006, Long Beach, CA, 1-30.

Shavinina, L. V. 2003. The International Handbook on Innovation. Pergamon. $1200 \mathrm{p}$.

Slater, S. F.; Narver, J. C. 1994. Does competitive environment moderate the market orientation-performance relationship?, Journal of Marketing 58(1): 46-55.

http://dx.doi.org/10.2307/1252250

Subramanian, A.; Nilakanta, S. 1996. Organizational innovativeness: exploring the relationship between organizational determinants of innovation, types of innovations, and measures of organizational performance, Omega 24(6): 631-647. http://dx.doi.org/10.1016/s0305-0483(96)00031-x

Tidd, J. 2000. From Knowledge Management to Strategic Competence: Measuring Technological, Market and Organizational Innovation. London: Imperial College Press. http://dx.doi.org/10.1142/p162

Trott, P. 2011. Innovation Management and New Product Development. 5th edition. Prentice Hall. 648 p.

Trott, P. 1998. Growing businesses by generating genuine business opportunities, Journal of Applied Management Studies 7(4): 211-222.

Varis, M.; Littunen, H. 2010. Types of innovation, sources of information and performance in entrepreneurial SMEs, European Journal of Innovation Management 13(2): 128154. http://dx.doi.org/10.1108/14601061011040221

Westhead, P.; Storey, D. J. 1994. An Assessment of Firms Located on and off Science Parks in the United Kingdom, HMSO, London. 210 p.

Wright, M.; Westhead, P.; Ucbasaran, D. 2007. Internationalization of small and medium-sized enterprises (SMEs) and international entrepreneurship: a critique and policy implications, Regional Studies 41(7): 1013-1030. http://dx.doi.org/10.1080/00343400601120288 